Article

\title{
A Cointegration Analysis of the Nordic Roundwood Markets
}

\author{
Victoria Eriksson 10 and Robert Lundmark * \\ ETS/Economics, Luleå University of Technology, SE-971 87 Luleå, Sweden; victoria.eriksson@ltu.se \\ * Correspondence: robert.lundmark@ltu.se; Tel.: +46-920-492346
}

Received: 18 August 2020; Accepted: 15 September 2020; Published: 18 September 2020

\begin{abstract}
The integration of the Nordic timber markets has been analysed to provide market information to various decision-makers, e.g., climate and industrial policies and investment decisions. This study addresses the interlinkage between Nordic (Sweden, Norway and Finland) roundwood markets (Scots pine (Pinus sylvestris L.)) and Norway spruce ((Picea abies L.) sawlogs and pulpwood). In total, eleven markets were analysed using quarterly data over the period 2006Q1-2017Q4 where various unit root and stationary tests were performed together with Johansen's cointegration test. In addition, directional causality analyses between the integrated markets were also performed. The results show that the law-of-one-price (LOP) hypothesis can be rejected for most of the studied markets and that no individual market emerges as the price-leader. Only the Swedish and Norwegian pine sawlog markets are integrated suggesting a single market for both countries. Price affecting national and forest-related policies as well as investments in the forestry sector, forest industries, bioenergy sector and other forest product using sectors, will not disperse into a larger international market structure; instead, the price effect will be national and more likely have a more profound effect.
\end{abstract}

Keywords: sawlogs; pulpwood; forest; unit root; stationarity; time-series

\section{Introduction}

It can be argued that understanding the transmission of prices between interlinked markets can help us understand competition issues, policy ramifications, arbitrage behaviour and investment patterns. In this context, market integration can be described as the comovement of prices and the transmission of price signals across markets. As such, comovement of prices can help establishing long-run market equilibrium and ensures that integrated markets share the same price information. In turn, this provides fundamental information to market actors in their production, investment or trade decisions. In the context of this study, integrated markets would suggest that roundwood prices would exhibit comovement across the Nordic markets. For example, if the pulpwood markets are integrated, then a price increase in pulpwood in Sweden due to e.g., climate policies would transmit to the other pulpwood markets.

Building on previous research, this paper evaluates multiple market relationships for the Nordic roundwood markets to provide enhanced knowledge for the complex societal choices that lie ahead. Specifically, the market integration between the pine and spruce sawlog and pulpwood markets in Sweden, Finland and Norway is evaluated using a cointegration approach. In addition, an analysis of the directional causality of the price fluctuations between cointegrated markets is also performed.

While roundwood prices may behave like random walks, in the long-run, it could be suspected that they drift in similar fashion. If this is the case, the prices are cointegrated, and the associated markets are integrated. However, even without cointegration, markets could still have a relationship. The price on one market might have the power to predict or even determine the price on another market. In this situation, a causality between the markets exists [1]. Cointegration characterises the long-run 
and causality characterises the short-run relationship between the market prices. Yet, even though theoretical advances have been made to our understanding of comoment of prices and market integration, the question basically remains an empirical question.

Studying the integration of the Nordic roundwood markets is important for several reasons. First, by determining the degree of market integration, it is possible to predict the consequences of future price fluctuations. With integrated markets, a price change in one market will affect the other markets, but the degree of market integration determines how much the price effect is balanced out between the markets. In addition, the effects of unexpected market shocks can better be understood if knowledge of market integration is available. Second, market conditions and competition are affected by the degree of market integration. For instances, for an appropriate (if not optimal) locational choice of production facilities, it is important to understand the integration of important feed-stock markets [2]. As such, the degree of market integration could give information on reginal, national and international competitive strengths and weaknesses. This also ties to the globalisation and consolidation of the forest industries in the Nordic countries. Third, the development of information technology is continuously improving and increasing the availability of market information. Consequently, arbitrage and speculative behaviour on the roundwood markets might increase. Fourth, an evaluation of market integration of roundwood markets might reveal institutional barriers and differences in legal environments between trading countries that affect the degree of integration. Finally, the lack of market integration could indicate an inefficient allocation of resources and that the economic welfare can be improved. This aspect is strongly connected to the design and implementation of policies. Not least the policy implications are important to understand from a market integration perspective. Both national and EU policy measures could facilitate an increasing market integration for roundwood.

\section{Previous Research}

There is an extensive literature on roundwood market integration. From a global perspective, Olmos and Siry [3] ask the question of if a single global market for pulpwood exists, using data between 1988 and 2012. They conclude that no such market exists but find evidence for integration of regional markets (e.g., Germany, Norway, Finland and Sweden). In addition, Chudy and Hagler [4] address the performance of global roundwood markets by evaluating market integration in several regions using quarterly data over the period 1995Q1-2017Q4. They conclude that the wood product markets are not integrated, with the exception for coniferous sawlog prices between Sweden and Finland.

Most studies have focused on the Nordic countries or North America. In a Nordic context, studies have examined cointegrated markets within a specific country. For instance, the integration of Finnish roundwood markets were evaluated by Toppinen and Toivonen [5] who studied the integration of monthly stumpage prices between 1985 and 1996 for pine and spruce sawlogs and pulpwood in four regions of Finland and concluded that only the pine sawlog markets are integrated. Twenty years later, Kuuluvainen et al. [6] investigated the linkages between domestic and import markets for coniferous sawlogs and pulpwood in Finland using monthly stumpage prices from 2002 to 2014 and found that the domestic and imported markets were cointegrated. The integration of Norwegian roundwood markets have also been studied $[7,8]$. They analysed the cointegration of the domestic, import and export spruce pulpwood markets in Norway for the years 1988-2000 and found that the Norwegian domestic and import markets were cointegrated. It is argued that the lack of cointegration between the domestic and exported markets is because domestic prices are based on long-term contracts, while the export prices are free to fluctuate with the demand. Sweden has received less attention: three regional pine and spruce sawlog markets in Sweden using annual data between 1999 and 2012 have been analysed [2]. They found that the regional markets were cointegrated. The central region was found to be a price-leader.

Another approach in the evaluation of market integration is to study the relationship between roundwood markets in different counties. In a Nordic context, Thorsen [9] investigated the relationship between Nordic spruce sawlog markets over the years 1951-1991 and concluded that they were 
cointegrated in the long-run, with Finland as the price-leader. Toivonen et al. [10] studied the relationship between pine and spruce sawlog and pulpwood markets in Austria, Finland and Sweden using annual data for 1980-1997 and concluded that only the Swedish and Finnish markets were integrated, with Finland as the price-leader. Mäki-Hakola [11] used monthly data for the period January 1994 to June 2001 to analyse the market integration of pine, spruce and birch pulpwood and pine and spruce sawlogs in Finland, Estonia, Lithuania and Germany. They concluded that only the pine pulpwood markets were fully integrated. Toppinen et al. [12] studied the relationship between the Finnish, Estonian and Lithuanian spruce, pine and birch sawlog and pulpwood markets using monthly data for the period 1996-2004. They found that only the Finnish and Lithuanian spruce sawlog markets and the Estonian and Lithuanian spruce sawlog markets were cointegrated. Hänninen et al. [13] investigated the relationship between markets for sawn wood and export markets of sawlogs from Finland, Austria Estonia and the Czech Republic to Germany using quarterly data between 1995 and 2003 and found a relationship between Finnish sawlog and sawn wood markets. Finally, Mutanen and Toppinen [14] studied the linkages between Finnish and Russian spruce, pine and birch sawlogs and pulpwood using quarterly data between 1998Q3 and 2005Q3 and found no evidence that the markets were integrated.

This study complements and expands previous studies by further adding empirical evidence to the degree of market integration for roundwood markets in the Nordic countries. This study focuses on the primary Nordic coniferous regions, i.e., Finland, Sweden and Norway, and on four disaggregated roundwood markets, i.e., pine and spruce sawlogs and pulpwood. As such, the findings provide further insights into the extent to which the geographically adjacent Nordic roundwood markets are integrated. In addition, updated data were used that capture recent developments on the demand and supply side of the roundwood markets.

\section{Materials and Methods}

\subsection{The Nordic Roundwood Markets}

The relationship between trade levels can be used as an indicator of market integration. However, trade statistics are lacking fundamental connection to market developments and are seldom collected for shipments between domestic regions. Instead, prices are a normally seen as the preferable indicator since they capture market fundamentals and incentives structures. Nevertheless, a brief description of the production and trade volumes of sawlogs, pulpwood and industrial roundwood are presented in Table 1 to give a contextual understanding of the market integration analysis. The markets are both spatially and product delineated. The spatial market delineation is based on national borders for Swede, Finland and Norway, while the product delineation is based on product (sawlogs and pulpwood) and species definitions (pine and spruce).

Table 1. Average annual production and trade volumes between 2006 and 2018 (million $\mathrm{m}^{3}$ ).

\begin{tabular}{lcccc}
\hline & $\begin{array}{c}\text { Production } \\
\text { Sawlogs }\end{array}$ & $\begin{array}{c}\text { Production } \\
\text { Pulpwood }\end{array}$ & $\begin{array}{c}\text { Import } \\
\text { Roundwood }\end{array}$ & $\begin{array}{c}\text { Export } \\
\text { Roundwood }\end{array}$ \\
\hline Finland & 20.62 & 20.53 & 2.80 & 0.71 \\
Norway & 4.70 & 4.08 & 0.94 & 2.04 \\
Sweden & 34.36 & 26.87 & 4.07 & 1.32 \\
\hline
\end{tabular}

Source: [15].

The Nordic roundwood markets have several features that make them interesting to analyse from a market integration perspective. They have similar ecological conditions and similar dominant tree species. In addition, they have comparable labour markets, an industrial focus towards pulp and sawn wood production, as well as employing and diffusing similar technical solutions. The transport infrastructure is also extensive between the countries and is not expected to act as a bottleneck for the 
integration of the markets. Finally, the institutional settings are comparable with considerable likeness in their historical development.

The average production and trade levels between 2006 and 2018 (in million $\mathrm{m}^{3}$ ) for Finland, Norway and Sweden are presented in Table 1. Sweden is the largest producer of both sawlogs and pulpwood followed by Finland. In comparison, Norway has relatively small production levels. Both Sweden and Finland are, on average, net importers, while Norway is a net exporter of roundwood. These figures tentatively suggest that it is more likely that the Swedish and Finnish markets are integrated, with one of them acting as the price-leader, and that the Norwegian markets behave more independently.

The historical production of pulpwood and sawlogs in Norway, Finland and Sweden between 2006 and 2018 is presented in Figure 1. Norway had a production volume around five million $\mathrm{m}^{3}$ of both sawlogs and pulpwood, showing a low positive trend. Finland had a production volume around 25 million $\mathrm{m}^{3}$ of both sawlogs and pulpwood in 2018, which is an increase by ten million $\mathrm{m}^{3}$ compared to the trough in 2009. Sweden exhibited the highest production volumes as well as the largest discrepancies between sawlogs and pulpwood. The trends were relatively stable over time with a production volume of pulpwood similar to that of Finland $\left(25\right.$ million $\left.\mathrm{m}^{3}\right)$ and around 35 million $\mathrm{m}^{3}$ sawlogs.

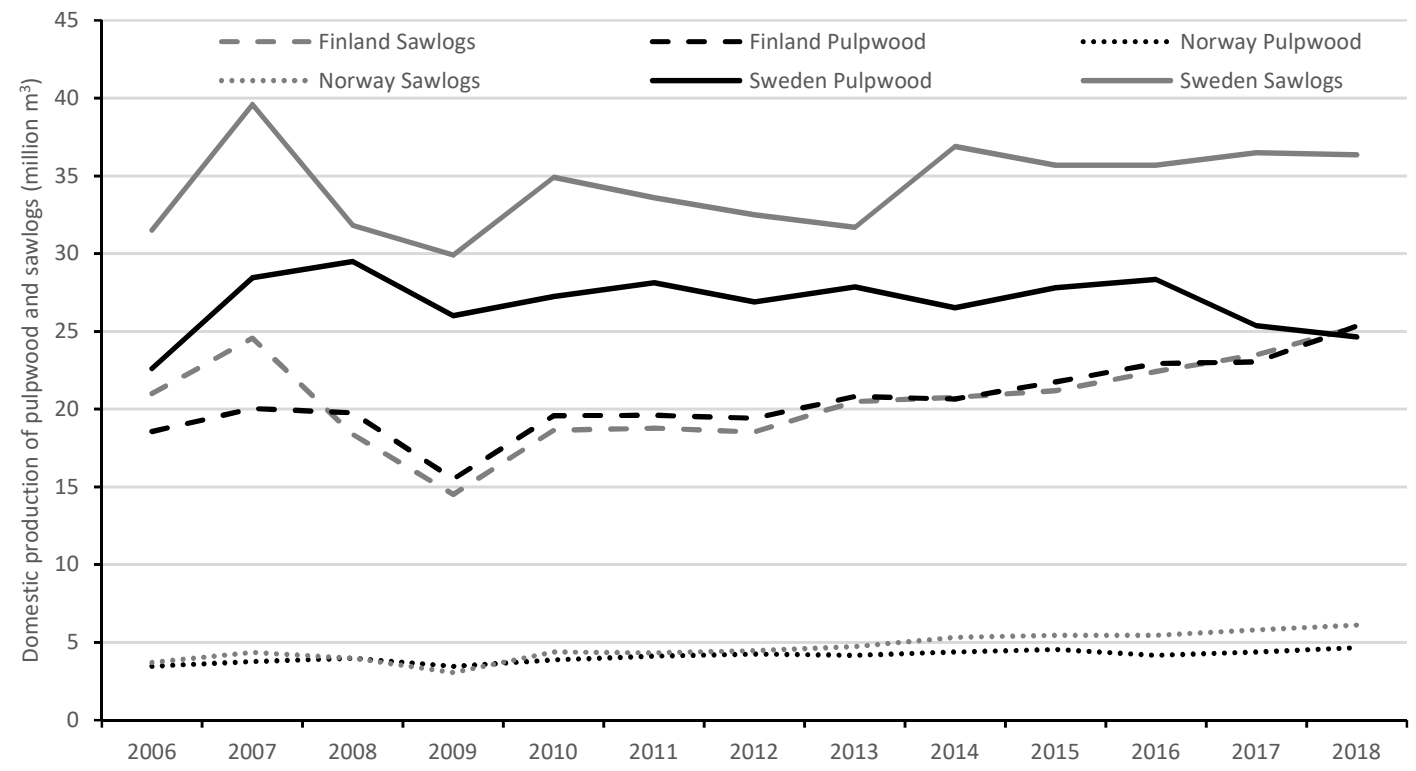

Figure 1. Production volumes of pulpwood and sawlogs in Norway, Finland and Sweden, 2006-2018 (million $\mathrm{m}^{3}$ ) Sources: [15].

Figure 2 illustrates the nominal price development of pine and spruce sawlogs and pulpwood in Sweden, Finland and Norway between 2006 and 2018 (EUR per $\mathrm{m}^{3}$ ). No data are available for pine pulpwood in Sweden. Compared to the pulpwood prices, sawlogs started the time-period with a higher volatility and with a larger price difference between the countries. A high volatility could be an indicator for poorly integrated markets. Furthermore, the price development illustrated in Figure 2 suggests that all countries were affected by common external drivers, especially after 2011. This is most clear for the price development of pine pulpwood where the three countries seemed to exhibit the same pattern. Tentatively, this suggests some kind of relationship, or linkage, between the markets. Prices that are nonstationary tend to have persistent shocks without a well-defined mean or variance, i.e., they will not return to their previous long-term trend after being exposed to an external shock. Instead, the price is prone to drift randomly in various directions [2]. 


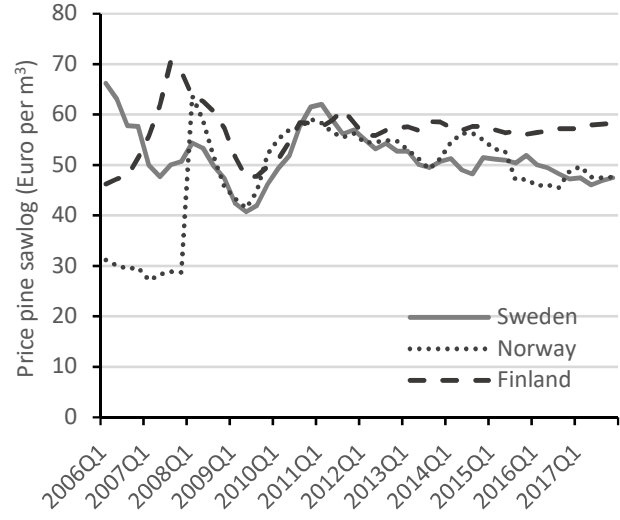

(a)

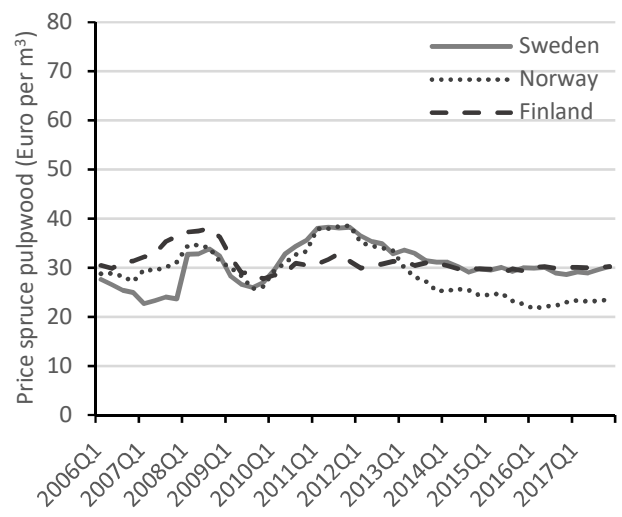

(c)

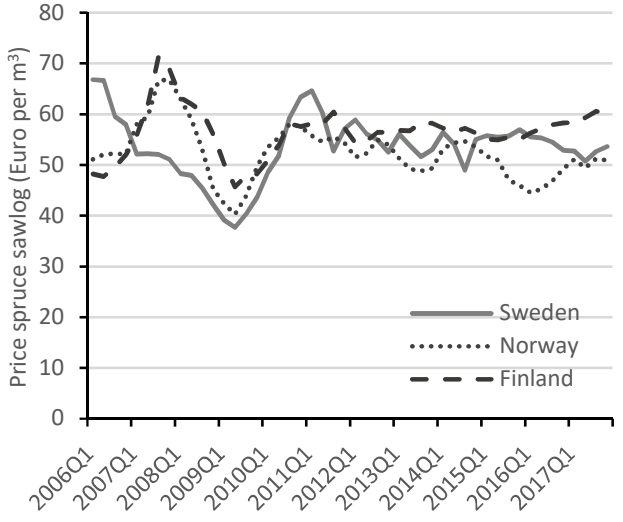

(b)

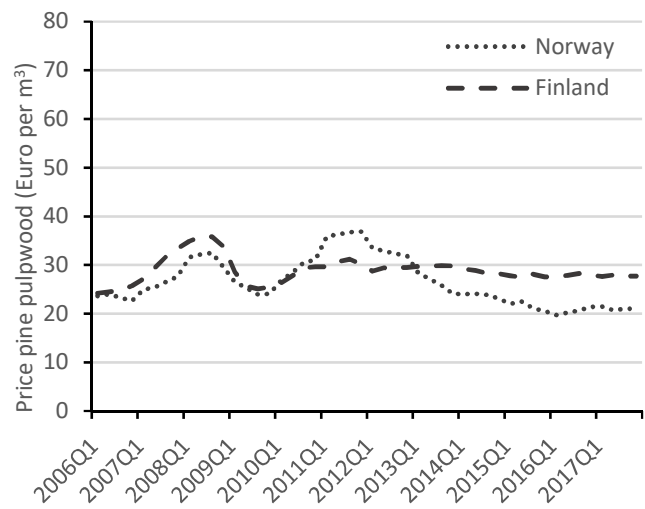

(d)

Figure 2. Nominal prices in Finland, Sweden and Norway between 2006 and 2018 (EUR per $\mathrm{m}^{3}$ ) for (a) pine sawlogs, (b) spruce sawlogs, (c) spruce pulpwood and (d) pine pulpwood. Sources: [16-18].

\subsection{Econometric Framework}

A common approach to evaluate price relationships between spatially separated markets is by conducting cointegration analyses. To analyse three price time-series, simultaneous certain approaches are more appropriate than others. For instance, the Engle-Granger test [19] is not applicable for more than two time-series and does not consider simultaneously determined prices, which might result in simultaneous biases [14,20,21]. Instead, the Johansen test was applied [22]. The test is based on a vector autoregressive (VAR) framework, with a lag length of $k$ observations and $p$ endogenous, nonstationary time series variables. The test model can be written as:

$$
\mathbf{p}_{t}=A_{1} \mathbf{p}_{t-1}+\cdots+A_{k} \mathbf{p}_{t-k}+\varepsilon_{t}
$$

where $\mathbf{p}_{t}$ is a vector of prices at time $t, A$ is parameters and $\varepsilon$ is an i.d.d. error term. From the Johansen test model, two test statistics were derived: the maximum eigenvalue test and the trace test. They both had the same null hypothesis of no cointegrated prices $(r=0)$, implying that there was no relationship between the prices.

To perform the Johansen test, the prices must be nonstationary in levels and stationary in first-difference. Nonstationary prices contain a unit root, meaning that a short-term economic shock will lead to permanent effects on the price equilibrium level. Hence, a new long-term trend will be reached. This is not true for stationary prices. Nonstationary prices will thus fluctuate with time, whereas stationary prices will eventually return to the initial level [2].

To evaluate the stationarity of the prices, three complementary tests were used. All three tests suffer from the same asymptotic properties (i.e., if the sample size is too small, the tests can under-reject 
the null hypothesis of nonstationarity when the data are in fact stationary). However, since they have different null hypothesis, these weaknesses will counteract each other, making them suitable complements [12]. First, the augmented Dickey-Fuller (ADF) test was used. The ADF is a unit root test and is implemented and evaluated with a constant $\left(a_{0}\right)$, and with and without a trend $\left(a_{1} t\right)$. The test equation can be expressed as (where the trend element is optional):

$$
\Delta p_{t}=a_{0}+\left(a_{1} T\right)+\gamma p_{t-1}+\sum_{i=1}^{k} \phi_{i} \Delta p_{t-i}+u_{t}
$$

where $T$ is a trend variable, $a$ and $\phi$ are constants, $u_{t}$ is the error term and $\gamma$ is the test statistics indicating whether the price series is stationary or not. The null hypothesis states that the price series contains a unit root, i.e., they are nonstationary $\left(H_{0}: \gamma=0\right)$.

The second unit root test is the Kwiatkowski, Phillips, Schmidt and Shin (KPSS) test [23]. Unlike the ADF test, the KPSS test is a stationarity test of the null hypothesis of trend stationarity against the alternative of a unit root:

$$
p_{t}=a_{0}+a_{1} T+\gamma Z_{t}+u_{t}
$$

where $a_{0}$ and $Z_{t}$ are stationary series. The null hypothesis states that the price series is stationary $\left(H_{0}: \gamma=0\right)$.

The third test is the Phillips-Perron (PP) test [24]. Unlike the ADF and KPSS tests, the PP test allows the possibility of breaks in the price series. As suggest earlier, the price series indicate possible breaks due to the financial crises 2008. The PP test is a unit root test and can be expressed as:

$$
p_{t}=a+\gamma p_{t-1}+u_{t}
$$

Unlike the ADF test, there is no need for the error term to possess i.i.d. properties when performing the PP test. The null hypothesis states that the price series contains a unit root, i.e., they are nonstationary $\left(H_{0}: \gamma=0\right)$.

The cointegration test does not provide any information on which of the price series is dependent. By investigating the directional causality of the cointegration, this can be determined. Thus, the directional causality can confirm if all variables are endogenous to each other, or it may distinguish a price leader from a price follower [2]. To evaluate the directional causality of cointegrated markets the Granger causality test was used. The test equation is expressed as:

$$
p_{t}=a+\sum_{j=1}^{k} b_{j} p_{t-j}^{x}+\sum_{j=1}^{k} c_{j} p_{t-j}^{y}+u_{t}
$$

where $x$ and $y$ represent different price areas, e.g., Nordic regions in our case, and $b$ and $c$ are constants. By not being able to reject the null hypothesis $\left(H_{0}: c_{j}=0\right)$ the price in region $x$ does not have an impact on the pricing in region $y$. A F-test was used since it performs better than the alternatives in time-series consisting of few observations [25].

\subsection{Data}

Roundwood prices were collected for sawlogs and pulpwood, subdivided into Scots pine (Pinus sylvestris) and Norway spruce (Picea abies), in Norway, Finland and Sweden. The time series consisted of quarterly, nominal prices for each assortment. Nominal prices were used to avoid obtaining misleading relationships between the price series [26]. This approach has also been applied in other similar studies, e.g., [12-14].

In total, eleven Nordic roundwood markets were included in the analysis since data on pine pulpwood prices were missing for Sweden. The Swedish and Norwegian prices were transformed to EUR by using monthly average exchange rates from the central banks of Sweden and 
Norway, respectively $[27,28]$. The price series were collected from the Swedish Forest Agency [16], Natural Resources Institute Finland [17] and Statistics Norway [18].

The data are available monthly for Norway and Finland but only on a quarterly basis for Sweden. To synchronise the time periods, the Norwegian and Finnish price series were converted to quarterly prices. The time series covered twelve years, from the first quarter of 2006 to the last quarter of 2017-in total 48 observations for each price series. Some missing observations for pine sawlogs in Norway made it necessary to replace the missing prices with an average price of the previous and preceding quarter. Finally, the logarithmic values of the price series are presented in Figure 3. This conversion was made to reduce the effect of heteroscedasticity [9].

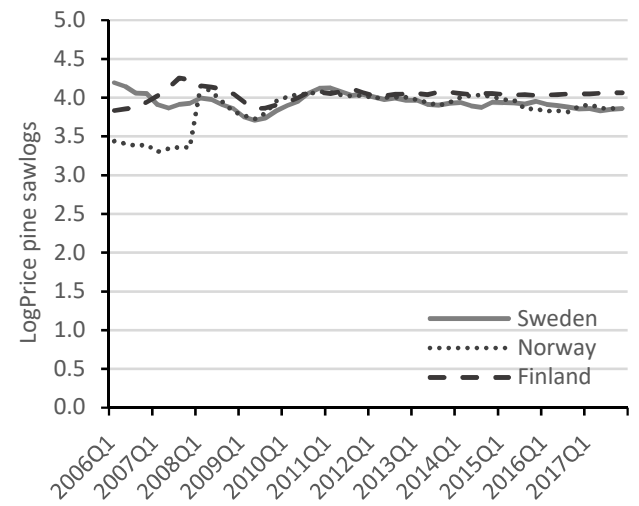

(a)

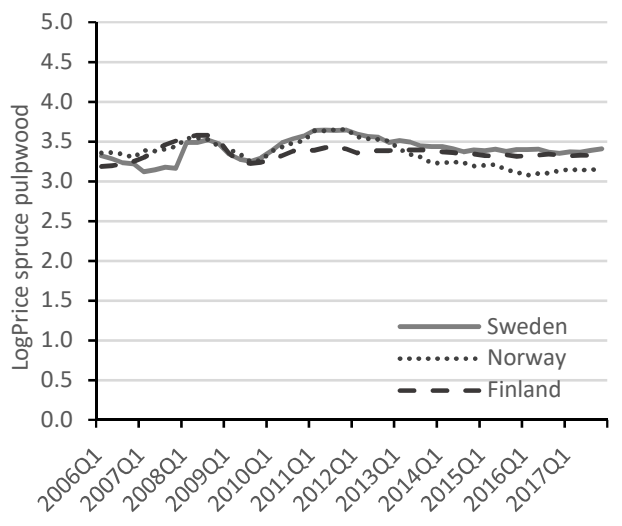

(c)

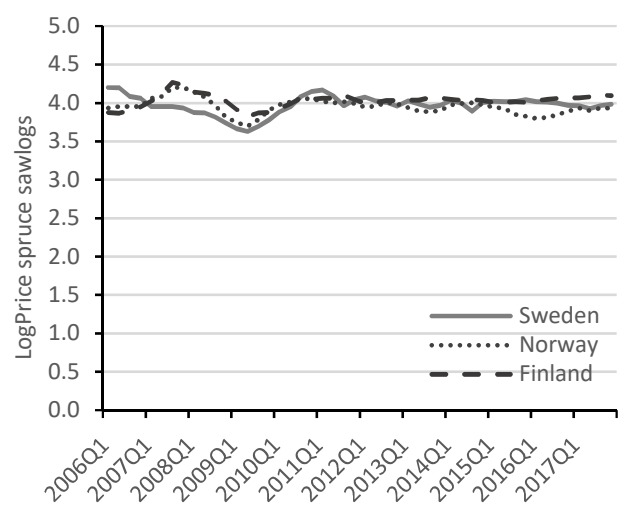

(b)

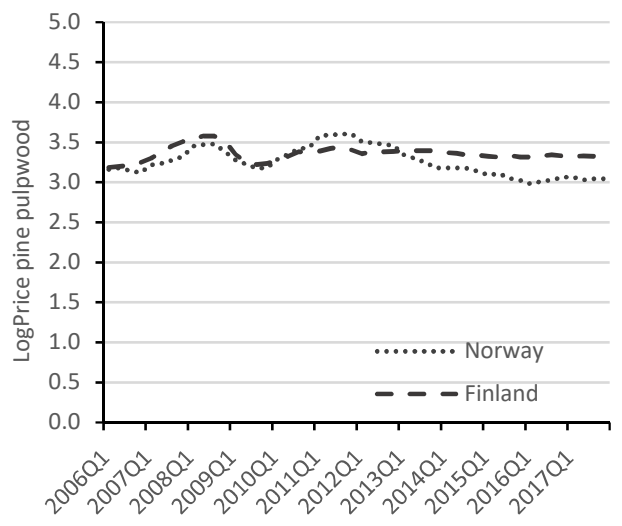

(d)

Figure 3. Logarithmic prices in Finland, Sweden and Norway between 2006 and 2018 for (a) pine sawlogs, (b) spruce sawlogs, (c) spruce pulpwood and (d) pine pulpwood.

\section{Results}

The unit root and stationary tests were performed under the assumption that the price series included a constant term and were implemented using Microfit 5.0 (Oxford University Press). However, the assumption that they include a trend or not was explicitly tested.

To determine the appropriate lag length $(k)$, two approaches are commonly used. It is possible to minimises the Akaike information criterion (AIC) or the Schwarz Bayesian information criterion (SBIC) (see [2]). None of the approaches are superior the others, but if they differ, the smallest one is recommended [29]. To select the appropriate lag length, both the AIC and SBIC were evaluated. However, studies using quarterly data are recommended to set a maximum lag length of six observations [30].

The stationarity tests were based on a two-step procedure. Table A1 presents the first step unit root and stationarity tests in which prices are in levels. Table A2 presents the second step tests in which prices are in first-difference and where the tests were only applied to the price-series that were found 
to be stationary (or inconclusive) in the first step. If the price-series were found to be nonstationary in levels and stationary at first-difference (i.e., I(1)) the cointegration analysis could be performed.

For Finland, the overall test results suggest that the price-series for pine and spruce sawlogs were stationary, while they were nonstationary for spruce pulpwood. For pine pulpwood, the results were inconclusive (ADF and KPSS suggested stationary, while PP suggested nonstationary). Pine pulpwood was not included in the second step of testing since only one of three tests supports nonstationarity. Thus, only spruce pulpwood was included in the second step of testing for Finland. The second step test suggested that the price-series in first-difference for spruce pulpwood was stationary. This indicates that Finnish spruce pulpwood prices were nonstationary in levels and stationary in first-difference, as required for the cointegration analysis.

For Norway, the tests indicated that the pine sawlogs and spruce pulpwood were nonstationary in levels (two of three tests for pine sawlogs) and carried over to the second step. The second step indicated that the price-series in first-difference for pine sawlogs and spruce pulpwood (without trend) were stationary. This indicates that Norwegian pine sawlogs and spruce pulpwood were nonstationary in levels and stationary in first-difference, as required for the cointegration analysis.

For Sweden, the ADF and PP tests indicated that the price-series were nonstationary in levels for all wood assortments. Since no obvious trend in the price-series could be observed, the KPSS tests suggested that all wood assortments were stationary in levels. Since two of three tests indicated nonstationarity, pine sawlogs and spruce pulpwood could continue to the second step of testing. However, stationarity in the other countries' price-series eliminated spruce sawlogs and pine pulpwood. In the second step, all tests (without trend) indicated that the price-series of pine sawlogs and spruce pulpwood was stationary in first-difference. This indicates that Swedish pine sawlogs and spruce pulpwood were nonstationary in levels and stationary in first-difference, as required for the cointegration analysis.

The two wood assortments passing the unit root and stationary tests, and thus included in the cointegration analysis, were pine sawlogs (between Sweden and Norway) and spruce pulpwood (between Sweden, Norway and Finland). The results for the cointegration analysis (based on Johansen test) are presented in Table 2. Both the maximum eigenvalue test and trace test were conducted. The parameter $r$ denotes the number of cointegration vectors present. If a cointegrated vector exists, there is a relationship between the price series, i.e., between the country's markets. The lag length $(k)$ was chosen based on the shortest length recommended by either AIC or SBIC.

Table 2. Tests results for cointegration analysis (Johansen test).

\begin{tabular}{ccccccc}
\hline & \multicolumn{5}{c}{ Maximum Eigenvalue Test } & \multicolumn{5}{c}{ Test } \\
\hline Pine sawlogs & $H_{0}$ & $H_{a}$ & Statistics & $H_{0}$ & $H_{a}$ & Statistics \\
Sweden-Norway & $r=0$ & $r=1$ & $14.48^{*}$ & $r=0$ & $r \geq 1$ & $20.13^{*}$ \\
$(k=1)$ & $r \leq 1$ & $r=2$ & 5.66 & $r \leq 0$ & $r=2$ & 5.66 \\
\hline Spruce pulpwood & $H_{0}$ & $H_{a}$ & Statistics & $H_{0}$ & $H_{a}$ & Statistics \\
Sweden-Norway-Finland & $r=0$ & $r=1$ & 8.93 & $r=0$ & $r \geq 1$ & 12.73 \\
$(k=1)$ & $r \leq 1$ & $r=2$ & 2.53 & $r \leq 1$ & $r \geq 2$ & 3.80 \\
& $r \leq 2$ & $r=3$ & 1.27 & $r \leq 2$ & $r=3$ & 1.27 \\
\hline Sweden-Norway & $r=0$ & $r=1$ & 4.62 & $r=0$ & $r \geq 1$ & 5.97 \\
$(k=1)$ & $r \leq 1$ & $r=2$ & 1.35 & $r \leq 0$ & $r=2$ & 1.35 \\
\hline Sweden-Finland & $r=0$ & $r=1$ & 13.4 & $r=0$ & $r \geq 1$ & 15.5 \\
$(k=2)$. & $r \leq 1$ & $r=2$ & 2.11 & $r \leq 0$ & $r=2$ & 2.11 \\
\hline Finland-Norway & $r=0$ & $r=1$ & 8.02 & $r=0$ & $r \geq 1$ & 9.60 \\
$(k=2)$ & $r \leq 1$ & $r=2$ & 1.58 & $r \leq 0$ & $r=2$ & 1.58 \\
\hline
\end{tabular}

* denotes a ten percent significance level.

The results indicate that one cointegrated vector was present for pine sawlogs, i.e., a relationship between Swedish and Norwegian pine sawlogs prices exists. However, no relationship could be found 
for spruce pulpwood, since the null hypothesis could not be rejected, i.e., no relationship between all three spruce pulpwood prices exists. Moreover, a bivariate test between the spruce pulpwood prices supports the overall results and revealed no relationship between the price-series for any pair of the countries.

Since the Swedish and Norwegian pine sawlog prices were found to be cointegrated, their directional causality could be evaluated. The optimal lag length $(k)$ was established the same way as previously. The Granger causality test is presented in Table 3. The results indicate that Swedish pine sawlog prices did not cause Norwegian pine sawlog prices, or vice versa. As such, none of the markets can be considered the price-leader. Since the markets were found to be cointegrated, a plausible explanation for this contradictive result is that markets are, from certain aspects, viewed as one single market by its agents.

Table 3. Granger causality test for pine sawlogs prices $(k=2)$.

\begin{tabular}{ccc}
\hline Directionality & $\boldsymbol{F}$-Stat & $\boldsymbol{p}$-Value \\
\hline Sweden $\longrightarrow$ Norway & 1.41 & 0.24 \\
Norway $\longrightarrow$ Sweden & 0.92 & 0.34 \\
\hline
\end{tabular}

\section{Discussion}

A general insight based on the results suggests that the Nordic roundwood markets are not integrated. Since the roundwood market are not integrated, the effects of markets shocks are not transferred across markets, i.e., the mitigating effect integrated markets have from market shocks is small. Consequently, the law-of-one-price hypothesis can generally be rejected. In addition, no individual market emerges as the price-leader.

Contrasting our results to those of previous studies reveals mixed patterns. For instance, the law-of-one-price hypothesis, at a national level in Finland and Sweden, is supported by Toppinen and Toivonen [5] and Jaunky and Lundmark [2], respectively. Integration of Nordic roundwood markets has also been reported by Riis [31]. Generally, our results suggest that the law-of-one-price hypothesis is not supported for Nordic roundwood markets, i.e., they are not integrated. This result is supported by the finding of e.g., [10-12,14]. However, some exceptions can be found in these studies: for instance, for spruce sawlogs [12] and for pine pulpwood [11], while we find an exception for pine sawlogs. It seems that the national roundwood markets are more integrated than their Nordic equivalents.

In contrast to global studies in roundwood market integration, the types and species of roundwood included in this study can be considered as having the same characteristics, i.e., Swedish spruce sawlogs can technically be substituted with Finnish spruce sawlogs. This might not be the case if a wider geographical range of roundwood markets are included due to variation in e.g., biological growth factors. However, there might be a perception of difference even between the Nordic roundwood markets. This has been illustrated by Lundmark and Shahrammehr [32-34] who estimated and analyzed Armington elasticities. They showed that imported and domestic roundwood in the Nordic countries are not necessarily perceived as identical commodities.

The analysis provided must be understood within its contextual and methodological framework. For instance, failure to find cointegration between markets does not suggest that they are not integrated. Instead, the identification failure might be masked by model specification errors or exclusions of appropriate regime shifts [35]. The absence of cointegration between the Nordic roundwood markets found in this study can, at least partly, be explained by a few factors. First, the analyzed roundwood assortments from the different markets are perceived as different by the users [32,33], even if they have the same physical and biological characteristics. Second, timber certification schemes might suggest that the relevant Nordic market delineations are not along geographical dimensions, but rather along a more precise product definition. Finally, transactions costs, not reflected by the market price, might limit the degree of market cointegration. Transaction costs in this context reflect the cost to physically move 
the roundwood from one market to another to arbitrage prices, more than the transportation cost. In some instances, markets might not have realistic trade/arbitrage options, and domestic prices may be driven more by local characteristics. The export of roundwood from the Swedish and Finnish roundwood markets to other Nordic markets has, as a percentage of harvesting levels, been relatively stable around 1-2 percent during the last decade. An interesting avenue for future research would be to identify and estimate these transaction costs.

From a policy perspective, the results provide some interesting insights. Since the results suggest that the Nordic roundwood markets are not integrated (with only one exception), stringent bioenergy policies might cause higher price effects than what would be the case otherwise. The price impact from the policies would be better dispersed by larger, integrated markets. On the supply-side, similar arguments can be used. For instance, preserving productive forest land, due to e.g., biodiversity or carbon sequestration, will drive roundwood prices upwards (ceteris paribus). Since the Nordic roundwood markets are not integrated, the price increase will have its full impact on the domestic market. As such, facilitating and improving the Nordic roundwood market integration might reduce the price impact of forest and energy polices.

\section{Conclusions}

In this study, the cointegration between the Nordic timber markets was analysed. In total, eleven price-series for four wood assortments in Finland, Norway and Sweden were analysed using several unit root and cointegration tests. The main conclusion is that the law-of-one-price (LOP) hypothesis can be rejected for the studied roundwood markets, except for pine sawlogs in Sweden and Norway, which are found to be cointegrated. In addition, no individual market emerges as the price-leader.

The finding that the Nordic roundwood markets are not cointegrated provide interesting insights. The relatively large volumes of roundwood traded between the Nordic countries might tentatively suggest that the markets are integrated, but, as our results suggest, they are not. Potential price impacts, whether driven by policies or market fundamentals, will remain domestic and will not diffuse across adjacent markets. That is, forest-related policies affecting market prices as well as investments in the forestry sector, forest industries, bioenergy sector and other forest product-using sectors, will not diffuse into a larger international market structure; instead, the price effect will be national and more likely have a more profound effect.

The transition to a bioeconomy relies on abundant and relatively nonexpensive biomaterials, of which forests are the predominantly supplier in the Nordic countries. Since the LOP hypothesis can be rejected, the price impact on the domestic market from an increasing utilisation will not diffuse across markets and will thus have its full impact on the local market. Moreover, for forest-related investment schemes, and their spatial localisation patterns, it becomes more important to consider possible effects on relevant feedstock markets. For example, marginal investment decision to increase e.g., pulp production, will result in an increasing demand for pulpwood and a price effect in the country receiving the investment. This price effect will not be reduced by diffusing into adjacent countries. Instead, the entire price impact must be considered when assessing if the investment is economically viable or not.

Author Contributions: Conceptualization, V.E. and R.L.; Methodology, V.E. and R.L.; Formal Analysis, V.E. and R.L.; Data, V.E.; Writing Original Draft Preparation, V.E. and R.L.; Writing Review \& Editing, R.L.; Visualization, R.L.; Project Administration, R.L.; Funding Acquisition, R.L. All authors have read and agreed to the published version of the manuscript.

Funding: This research received no external funding.

Acknowledgments: We thank Bio4Energy, a Strategic Research Environment appointed by the Swedish government, for supporting this work.

Conflicts of Interest: The authors declare no conflict of interest. 


\section{Appendix A}

Table A1. Unit root and stationarity test results (prices in levels).

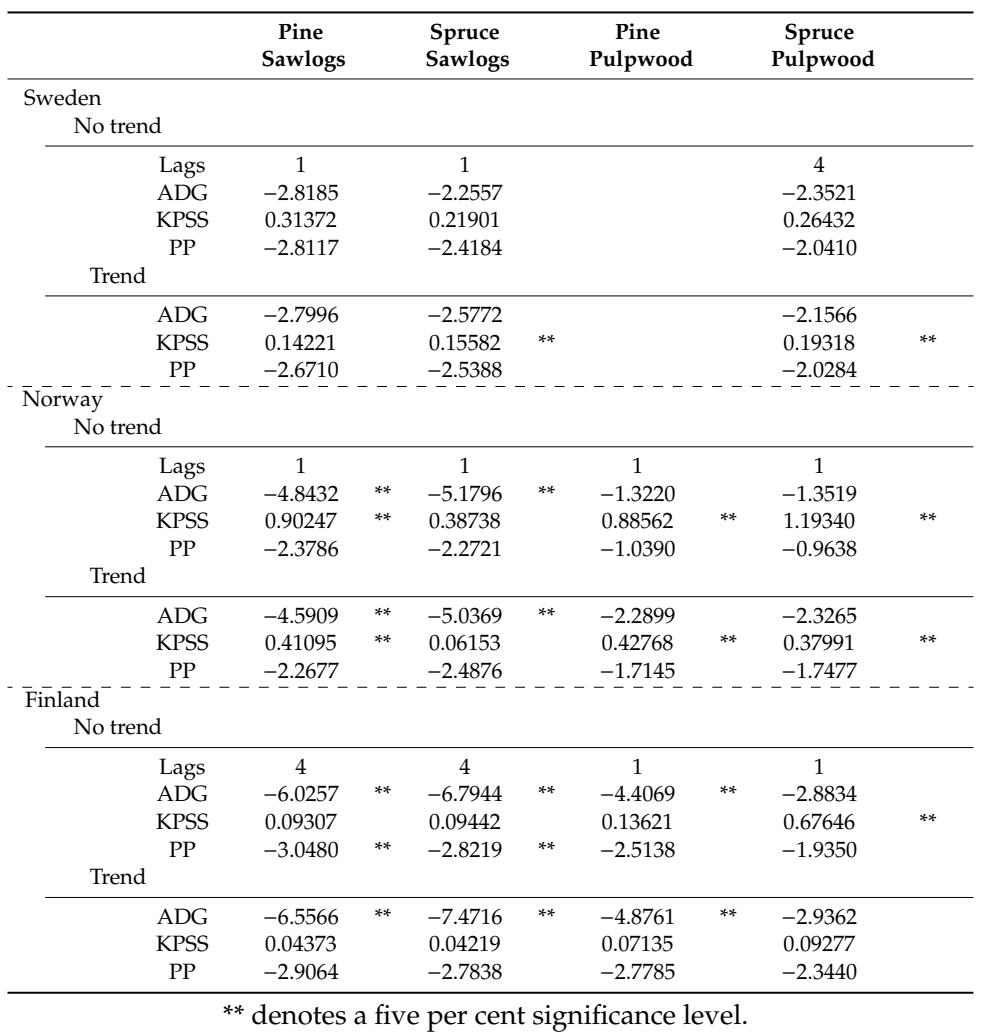

Table A2. Unit root and stationarity test results (prices in first-difference).

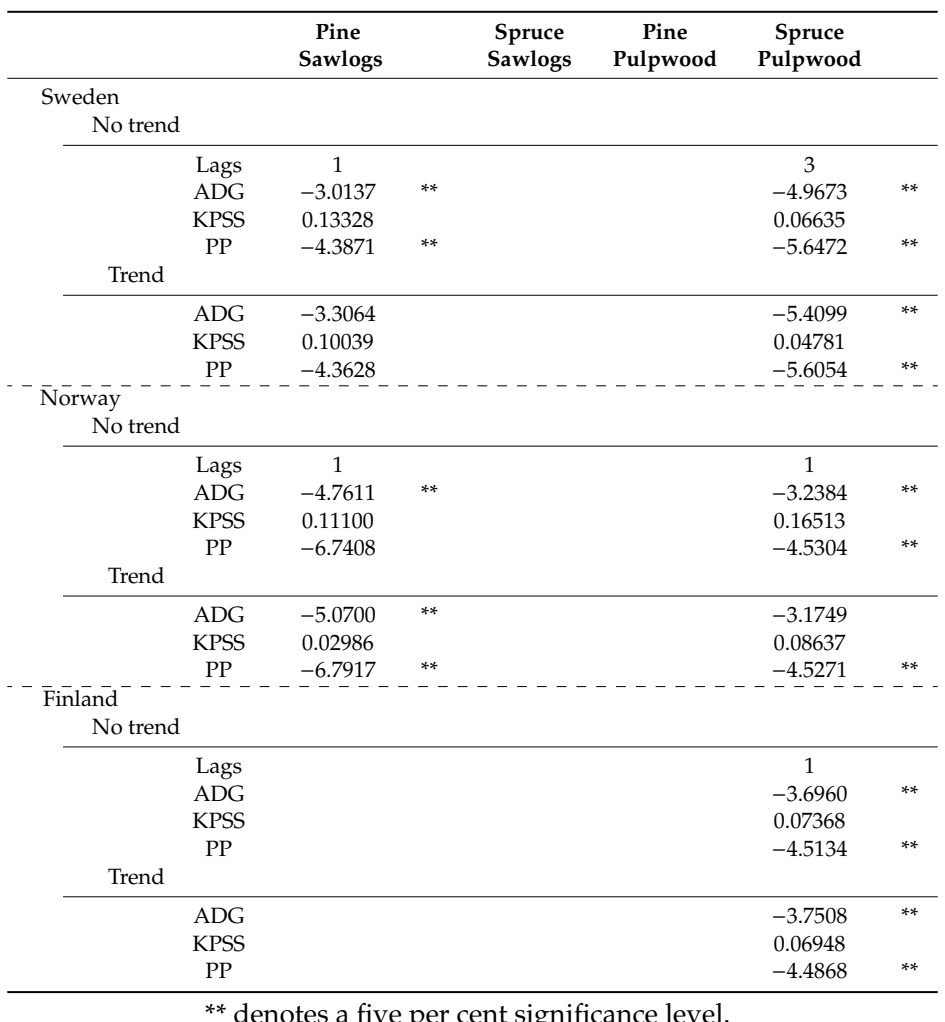




\section{References}

1. Granger, C.W.J. Causality, cointegration and control. J. Econ. Dyn. Control. 1988, 12, 551-559. [CrossRef]

2. Jaunky, V.; Lundmark, R. Dynamics of Timber Market Integration in Sweden. Forests 2015, 6, 4617-4633. [CrossRef]

3. Olmos, V.; Siry, J. Global Pulpwood Markets and the Law of One Price. Math. Comput. For. Nat. Resour. Sci. 2015, 7, 16-32.

4. Chudy, R.P.; Hagler, R.W. Dynamics of global roundwood prices-Cointegration analysis. For. Policy Econ. 2020, 115, 102155. [CrossRef]

5. Toppinen, A.; Toivonen, R. Roundwood market integration in Finland: A multivariate cointegration analysis. J. For. Econ. 1998, 4, 241-265.

6. Kuuluvainen, J.; Korhonen, J.; Xu, D.; Toppinen, A. Price integration for domestic and imported sawlogs and pulpwood in Finland: An update. Scand. J. For. Res. 2018, 33, 71-80. [CrossRef]

7. Stoerdal, S.; Nyrud, A. Testing roundwood market efficiency using a multivariate cointegration estimator. For. Policy Econ. 2003, 5, 57-68. [CrossRef]

8. Nyrud, A. Integration in the Norwegian pulpwood market: Domestic prices versus external trade. J. For. Econ. 2002, 8, 213-225.

9. Thorsen, B. Spatial integration in the Nordic timber market: Long-run equilibria and short-run dynamics. Scand. J. For. Res. 1998, 13, 388-398. [CrossRef]

10. Toivonen, R.; Toppinen, A.; Tilli, T. Integration of roundwood markets in Austria, Finland and Sweden. For. Policy Econ. 2002, 4, 33-42. [CrossRef]

11. Mäki-Hakola, M. Cointegration of the Roundwood Markets Around the Baltic Sea-An. Empirical Analysis of Roundwood Markets in Finland, Estonia, Germany and Lithuania; Working Papers No 55; Pellervo Economic Research Institute: Helsinki, Finland, 2002.

12. Toppinen, A.; Viitanen, J.; Leskinen, P.; Toivonen, R. Dynamics of roundwood prices in Finland, Estonia and Lithuania. Balt. For. 2005, 11, 88-96.

13. Hänninen, R.; Toppinen, A.; Toivonen, R. Transmission of price changes in sawn wood and sawlog markets of the new and old EU member countries. Eur. J. For. Res. 2007, 126, 111-120. [CrossRef]

14. Mutanen, A.; Toppinen, A. Price dynamics in the Russian Finnish roundwood trade. Scand. J. For. Res. 2007, 22, 71-80. [CrossRef]

15. FAO_Food and Agriculture Organization of the United Nations. FAOstat-Forestry Statistics. Available online: www.fao.org (accessed on 13 May 2019).

16. Swedish Forest Agency. Quarterly Average Prices by Region, Assortment and Year, Tertial/Quarter. Available online: http://pxweb.skogsstyrelsen.se (accessed on 2 June 2019).

17. Natural Resources Institute Finland. Roadside Prices of Roundwood by Month. Available online: http: //statdb.luke.fi (accessed on 28 May 2019).

18. Statistics Norway. Commercial Roundwood Removals: Average Price, by Assortment (NOK per $\mathrm{m}^{3}$ ) 2006-2017. Available online: www.ssb.no (accessed on 28 May 2019).

19. Engle, R.F.; Granger, C.W.J. Co-Integration and Error-Correction: Representation, Estimation, and Testing. Econometrica 1987, 55, 251-276. [CrossRef]

20. Nanang, D. A multivariate cointegration test of the law of one price for Canadian softwood lumber markets. For. Policy Econ. 2000, 1, 347-355. [CrossRef]

21. Jung, C.; Doroodian, K. The Law of One Price for U.S. Softwood Lumber: A Multivariate Cointegration Test. For. Sci. 1994, 40, 595-600.

22. Johansen, S. Estimation and Hypothesis Testing of Cointegration Vectors in Gaussian Vector Autoregressive Models. Econometrica 1991, 59, 1551-1580. [CrossRef]

23. Kwiatkowski, D.; Phillips, P.C.B.; Schmidt, P.; Shin, Y. Testing the Null Hypothesis of Stationarity against the Alternative of a Unit Root. J. Econom. 1992, 54, 159-178. [CrossRef]

24. Phillips, P.C.B.; Perron, P. Testing for Unit Roots in Time Series Regression. Biometrika 1988, 75, 335-346. [CrossRef]

25. Parajuli, R.; Tanger, S.; Joshi, O.; Henderson, J. Modelling Prices for Sawtimber Stumpage in the South-Central United States. Forests 2016, 7, 148. [CrossRef] 
26. Bingham, M.; Prestemon, J.; MacNair, D.; Abt, R. Market structure in U.S. southern pine roundwood. J. For. Econ. 2003, 9, 97-117.

27. Riksbanken. Monthly Average Exchange Rates. Available online: www.riksbank.se (accessed on 13 May 2019).

28. Norges Bank. Exchange Rate for Euro (EUR). Available online: www.norges-bank.no (accessed on 13 May 2019).

29. Pesaran, B.; Pesaran, M. Time Series Econometrics Using Microfit 5.0; Oxford University Press: Oxford, UK, 2009.

30. Brandt, P.; Williams, J. Multiple Time Series Models; Sage Publications: New York, NY USA, 2007.

31. Riis, J. Forecasting Danish timber prices with an error correction model. J. For. Econ. 1996, 2, $257-272$.

32. Lundmark, R.; Shahrammehr, S. Sweden's import substitution possibilities for roundwood. Scand. J. For. Res. 2011, 26, 146-153. [CrossRef]

33. Lundmark, R.; Shahrammehr, S. Forest biomass and Armington elasticities in Europe. Biomass Bioenergy 2011, 35, 415-420. [CrossRef]

34. Lundmark, R.; Shahrammehr, S. Armington elasticities and induced forest commodity specialisation in Europe. J. Nat. Resour. Policy Res. 2012, 4, 161-170. [CrossRef]

35. Von Cramon-Taubadel, $\mathrm{S}$. The analysis of market integration and price transmission-Results and implications in an African context. Agrekon 2017, 56, 83-96. [CrossRef]

(C) 2020 by the authors. Licensee MDPI, Basel, Switzerland. This article is an open access article distributed under the terms and conditions of the Creative Commons Attribution (CC BY) license (http://creativecommons.org/licenses/by/4.0/). 